\title{
KEPEMIMPINAN DALAM ISLAM SERTA PRINSIP-PRINSIP PEMERINTAHAN DALAM AL-QURAN
}

\author{
Hemlan Elhany \\ Institut Agama Islam Negeri (IAIN) Metro \\ Jl. Ki Hadjar Dewantara 15 A Kota Metro Lampung 34111 \\ hemlanceraci@gmail.com
}

\begin{abstract}
Abstrack
Immediately, after the Prophet Muhammad received the revelation he began his prophetic mission. Through a very heavy struggle, for 13 years in Mecca, he only gained followers of no more than 100 people. After migrating to Medina, he gained a lot of sympathy and followers, even able to build a free and independent Islamic community under the leadership of the Prophet. In this city of Medina, in less than two years, he has published a charter which regulates the life and relationships between such diverse communities. The charter is known as the Charter of Medina (ShohifahMadinah). In the 10-year period the Prophet in Medina had built a (civilized) society, civil society. In this country of Medina, for Muslims, the Prophet Muhammad is everything. He is the Apostle of Allah with authority based on prophethood as well as community leader and head of state, head of government. He became the leader of God's decree. As a leader sharing decisions is taken through deliberation, and if the decision is determined based on his personal instincts he always controls by divine revelation. The Qur'an is a perfect norm of life for mankind. In there are concepts about ethics, politics, economics, and society. There are a number of verses that contain instructions and guidelines in the life of society and the state, in terms of leadership and government.
\end{abstract}

Keyworad: pemimpin, islam, pemerintahan dalam al qur'an 


\section{A. PENDAHULUAN}

Dalam terminologi Islam ada istilah yang diberi lebih dari satu makna, yaitu istilah "Khilafah". Istilah ini pada suatu sisi diberi arti "imamah" (kepemimpinan), dan pada sisi yang lain diartikan dengan "imarah" (pemerintahan). Didalam Al-Quran terdapat sebanyak 23 ayat yang tersebar pada 13 surat yang mengunakan istilah khilafah yang digolongkan dalam arti "imarah" ( pemerintahan). Dan sebanyak 10 ayat pada 4 surat yang digolongkan dalam arti "imamah" (kepemimpinan). ${ }^{1}$ Namun, secara lebih jelas, dalam Al-Quran dapat ditemukan sejumlah kata yang pada prinsipnya memiliki makna yang sangat berdekatan. Kata (istilah) tersebut seperti: kata khilafah, imamah, imarah, dan al-mulk (kerajaan), tidak dimaksudkan dalam Al-Quran selain kepemimpinan dalam pengertian umum, dan tidak dimaksudkan pada sistem pemerintahan tertentu. Identifikasi mengenai istilah dan terhadap sejumlah ayat dan surat dalam Al-Quran, dalam rangka mendahului tulisan ini, tidak dimaksudkan untuk membuka wacana diskusi di sekitar "terminologi" tentang tema yang akan ditelaah, melainkan akan memberikan suatu wacana pemahaman dan menjadikannya sebagai bahan referensi pedoman pembahasaan yang lebih terfokus. Tulisan ini hanya akan berbicara di sekitar subtema yang lebih spesifik yaitu mengenai prinsip-prinsip pemerintahan sepanjang yang terdapat dalam kandungan ayat Al-Quran.

Bahwa Al-Quran merupakan suatu norma kehidupan yang sempurna untuk umat manusia dalam seluruh perjalanan hidupnya. Di dalam AlQuran terdapat konsep-konsep tentang etika, politik, ekonomi, dan masyarakat. ${ }^{2}$ Di dalam Al-Quran memang terdapat sejumlah ayat yang mengandun petunjuk dan pedoman bagi manusia dalam hidup bermasyarakat dan bernegara, mengenai kepemimpinan dan pemerintahan.

Guna memenuhi tuntutan tema pada bagian I, sistem kepemimpinan akan di deskripsikan secara selayang pandang, yaitu sistem keemimpinan dalam Islam yang telah berlangsung selama ini semenjak Rasulullah SAW sampai memasuki masa yang panjang sesudahnya, serta berbagai pemikiran yang relevan pada bagian II. Analisis mengenai prinsip-prinsip pemerintahan, sebagai tema pokok, dilakukan atas dasar perpsektif para pemikir muslim di bidang politik, ketata-negaraan dan pemerintahan, serta interprestasi para ahli tafsir Al-Quran.

\section{B. KEPEMIMPINAN DALAM ISLAM}

Kepemimpinan (Pemimpin) dalam Islam adalah sebuah tuntutan syar'i. Hal ini disyaratkan oleh Rasulullah SAW sebagaimana sabdanya

\footnotetext{
${ }^{1}$ A fazlurrahman, Indeks Al-Quran (Jakarta: Bumi Aksara, 1997).h.170

2 A fazlurrahman.h.121
} 
yang berbunyi: "Apabila bepergian tiga orang dalam perjalanan maka hendaklah mereka mengangkat salah satu diantaranya untuk menjadi pemimpin" (HR. Abu Dawud). ${ }^{3}$ Lebih jauh Allah menegaskan dalam berbagai surat dan dalam berbagai ayat Al-Quran, diantaranya surat AlAnbiya (21) ayat 73, yang artinya: "Kami telah menjadikan mereka sebagai pemimpin-pemimpin yang memberi petunjuk dengan perintah kami dan telah kami wahyukan kepada mereka agar mengajarkan kebajikan, mendirikan sholat, menunaikan zakat, dan hanya kepada kami mereka menyembah". ${ }^{4}$ Dalam surat As-Sajdah (32) ayat 24, artinya: "dan kami jadikan diantara mereka pemimpin-pemimpin yang memberi petunjuk dengan perintah kami ketika mereka sabar, dan mereka meyakini ayat-ayat kami." 5

Dari ayat-ayat Al-Quran dan Hadits diatas menunjuk adanya keharusan bagi orang-orang yang beriman untuk mengangkat para pemimpin yang dalam kepemimpinannya harus berpedoman kepada perintah dan ajaran Allah, harus berlandaskan syariat.

\section{Kepemimpinan semasa Nabi SAW}

Segera, setelah Nabi Muhammad SAW menerima wahyu beliau memulai misi kenabiaannya (prophotic-vision). Melalui perjuangan yang amat sangat berat, selama 13 tahun di Mekkah, beliau hanya memperoleh pengikut tidak lebih dari 100 orang saja. Setelah hijrah ke Madinah barulah beliau memperoleh simpati dan pengikut yang banyak, bahkan telah dapat membangun satu komunitas Islam yang bebas dan merdeka dibawah pimpinan Nabi. Di Kota Madinah ini, kurang dari dua tahun, beliau telah mempermaklumkan satu piagam yang mengatur kehidupan dan hubungan antar komunitas yan begitu majemuk. Piagam tersebut dikenal dengan Piagam Madinah (Shohifah-Madinah). ${ }^{6}$ Dalam masa 10 tahun Nabi di Madinah telah dibangun suatu masyarakat yang berperadaban (modern), masyarakat madani. Di negara Madinah ini, bagi umat Islam, Nabi Muhammad adalah segala-galanya. Beliau adalah Rasul Allah dengan otoritas yang berlandaskan kenabian sekaligus pemimpin masyarakat dan kepala negara, kepala pemerintahan. Beliau

\footnotetext{
${ }^{3}$ Imam Nawawi, Riadhus-Sholihin, II (Jakarta: Pustaka Amani, tt).h.96

4 Departemen Agama RI, Al-Quran Dan Terjemahannya (Surabaya: Mahkota, 1989).h.504

5 Departemen Agama RI.h.663

6 Piagam Madinah (Madinah-charter) berisi 47 butir pernyataan, yang intinya menyangkut dua hal, yaitu bahwa: semua pemeluk Islam meskipun berasal dari berbagai suku tetapi merupakan satu komunitas. Bahwa hubungan antara komunitas Islam dan komunitas lainnya didasarkan pada prinsip-prinsip: bertetangga baik, saling bantu, saling menasehati, dan menghormati kebebasan beragama. (Baca: Munawir Syadzali, Islam dan Tata Negara, Jakarta, UI Press, 1993), h.9-16.
} 
menjadi pemimpin atas ketetapan Tuhan. Sebagai seorang pemimpin berbagi keputusan diambil melalui musyawarah, dan apabila keputusan yang ditetapkan berdasarkan naluri pribadinya beliau selalu kontrol oleh wahyu Ilahi.

\section{Kepemimpinan masa Khulafaur-Rasyidin}

Setelah Nabi Muhammad wafat kepemimpinan dilanjutkan oleh penggantinya, yaitu para Khalifah Khulafaur-Rasyidin. Pengangkatan para Khalifah didasarkan atas musyawarah walaupun dalam pola musyawarah yang beragama, karena memang tidak ada pola yang baku berkenaan dengan pola pengangkatan khalifah (pemimpin) atau kepala negara. Abu Bakar dipilih menjadi khalifah pertama dalam satu pertemuan yang berlangsung antara tokoh-tokoh Muhajirin dan Anshor hari kedua wafatnya Nabi. Dalam musyawatrah terbuka itu hanya lima orang yang hadir mewakili semua unsur yang ada. Umar bin Khattab diagkat melalui penunjukan (rekomendasi ) pendahulunya, tidak melalui pemilihan dalam pertemuan terbuka, namun telah dikonsultasikan terlebih dahulu dengan beberapa shabat senior. Usman bin Affan diangkat melalui sebuah pertemuan terbuka oleh "dewan formatur" (yang dikenal dengan ahlul halli wal-aqd). ${ }^{7}$ Keabsahannya ditolak oleh sebagian masyarakat terutama dari kelompok Muawiyah bin Abi Sufyan. Fenomena pengangkatan Ali sebagai Khalifah dalam situasi suara yang tidak bulat membuahkan suatu pemerintahan yang penuh pemberontakan dan pada gilirannya mencapai titik kritis terjadinya desintegrasi umat.

\section{Kepemimpinan Pasca Khulafaur-Rasyidin.}

Pada masa Khulafaur-Rasyidin suksesi kepemimpinan berlangsung secara musyawarah dengan kontrak sosial.8ditandai prosesi simbolik dengan bai'at. ${ }^{9}$ Sistem musyawarah terbuka ini merupakan pola baku

${ }^{7}$ Ahlul-halli wal-aqdi diberi makna identik dengan Ahl Al-Syura atau Majelis Permusyawartan. Menurut Al-Maududi, bahwa yang termasuk kelompok ini adalah orangorang yang secara terus menerus memegang kedudukan yang sangat dipercaya selama jangka waktu lama dan dengan demikian dibei hak untuk mengambil keputusan bersama mengenai semua masalah penting yang menyangkut umat. Diantara mereka itu ialah, seperti ucapan Ali bin Abi Thalib, semua orang yang dapat memberikan saran dan telah berperang dalam peperangan Badr (ahl al-Syura wa ahl al-Badr). Baca: Abd A'la Al-Maududi, Hukum dan Konstitusi Sistem Politik Islam, (Bandung, Penerbit Mizan, 1995), terjemahan Asep Hikmat, h. 262.

8 Dalam Kontrak Sosial hubungan antara Khalifah dengan umat merupakan hubungan antara dua peserta dari suatu kesepakatan, yang memebrikan kepada msingmasing hak dan kewajiban atas dasar timbal balik tercermin dalam bai'at yang disusul dengan pidato pengukuhan. (Munawir Syadzali, Op. Cit., h.31)

9 Bai'at ada dua macam, yaitu Bai'at khusus dan Ba'iat umum. Bai'at khusus dilakukan oleh Dewan Permusyawaratan (Ahl-hall wal-aqd). Bai'at umum dilakukan setelah bai'at khusus yang merupakan pernyataan atau ikrar kesetiaan, ketaatan dan pengakuan atas pemerintahan yang berkuasa. Bai' at khusus merupakan dari bai'at umum dalam situasi 
pada masa itu. Dengan wafatnya Ali bin Abi Thalib, khalifah keempat maka berakhirlah era Khulafaur-rasyidin, dan sejak itu pula berakhirlah tradisi pengisian jabatan kepala Negara (Khalifah) melalui musyawarah. Mu'awiyah bin Abu Sufyan mendapat keududukan menjelang khalifah melalui ketajaman pedang dan tipu muslihatnya. Menjelang akhir hayatnya Mu'awiyah menunjuk Yazid, putranya, sebagai calon penggantinya. Dan fenomena seperti ini berlanjut pada masa Dinasti Umayyah berkuasa, sampai digantikan oleh daulah Abasyiyah yang ternyata memantapkan tradisi pendahulunya dalam hal penggantian kekuasaan. Pemerintahakan dijalankan dengan sistem monarki, dimana pengisian jabtan kepala Negara (khalifah) ditemukan atas dasar keturunan ( dynastic). ${ }^{10}$ Menarik untuk disimak, bahwa meskipun kedua dinasti, Mu'awiyah dan Abbasyiyah, telah menyimpang dari tradisi yang bersifat demokratik, dalam hal pengangkatan Khalifah, menjadi bercorak monarki, para khalifah Umaiyah menganggap bahwa jabatan Khalifah adalah suatu lembaga politik (pemerintahan) semata, tanpa pretensi bahwa mereka memiliki otoritas keagamaan sebagai wakil Tuhan di bumi. Sedang pada kekhalifahan dinasti Abasyiyah, yang kemungkinan pengaruh alam pikiran Persia pra-Islam, berkembang paham bahwa khalifah memerintah berdasarkan mandat dari Tuhan dan bukan dari rakyat. Oleh karenanya kekuasaan khalifah adalah suci dan mutlaq.

\section{Kepemimpinan Menurut Pemikir Muslim Masa Klasik dan Pertengahan.}

Uraian secara dalam beberapa point diatas berkenaan dengan sistem Kepemimpinan Islam sebagai suatu relitas yang sudah berlangsung. Berikut ini abstraksi mengenai pemikiran beberapa tokoh pemikir, sarjana Muslim, yang mencurahkan perhatiannya begitu antusias mengenai bagaimana sebaiknya sistem kepemimpinan dalam politik atau pemerintahan Islam pada umumnya. Mereka itu ialah Ibnu Abi Rabi', AlFarabi, Mawardi, Al-Ghazali, Ibnu Taimiyah yang hidup setelah runtuhnya kekuasaan Abasyiyah di Baghdad, dan Ibnu Khaldun yang hidup di Abad IV M. Mereka ini dianggap sebagai eksponen yang

ketika terjadi suksesi kepemimpinan. (Lihat: RKAS. Abdurrahman, Bai'at Satu Prinsip Gerakan Islam, (Jakarta, Elfawaz Press, 1993), terjemahan Bambang Syaiful Maarif, h.48

10 Sejak pengangkatan Abu Bakar, Umar, Usman dan Ali sebagi khalifah Rasul menjadi dasar terbentuknya model pemerintahan Khilafah dalam sejarah Islam yang berlanjut pada Dinasti Umayyah di damaskus, Dinasti Abasyiyah di Bagdad, Dinasti Umaiyah di Spanyol, Dinasti Fatimiah di Mesir, Turki Usmani di Istambul, Safawi di Persia, dan Kerajaan Mogul di India.Model pemerintahan khilafah dunia Islam berakhir diTurki sejak Mustafa Kemal At-Taruk menghapusnya pada tanggal 3 Maret 1924. (Lihat: Dewan Redaksi Ensiklopedia Islam. Ensiklopedia Islam 3, (Jakarta, Ikhtiar Baru Van Hove, 1993) h. 52. 
mewakili pemikir di bidang politik (pemerintahan) di dunia Islam periode klasik dan pertengahan.

Munawir Syadzali, dalam bukunya Islam dan Tata Negara,(terbit tahun 1993), seteah membahas secara intensif mengenai pemikiran politik keenam tokoh tersebut, menyimpulkan bahwa hanya Al-Farabi satusatunya yang mengadakan idealisasi tentang segi-segi dan perangkat kekhalifahan bernegara yang lebih banyak mencerminkan pengaruh alam pikiran Yunani Purba dari pada pengaruh Islam. Lima pemikir Islam lainnya lebih cenderung pada realistis sistem monarki yang ada, yang tidak diragukan lagi keabsahannya. Mengenai teori tentang asal-usul timbulnya negara keenam pemikir tersebut mirip satu sama lain. Hanya saja mengenai beberapa aspek tentang pemimpin (Kepala Negara) terdapat seikit ketidaksepakatan.

Ibnu Abi Rabi', Ghazali dan Ibnu Taimiyah dengan tegas menyatakan bahwa kekuasaan kepala Negara atau Raja (khalifah) merupakan mandat dari Allah yang diberikan kepada hamba-hamba pilihan-Nya. Khalifah adalah bayangan Allah dari bumi, dan mereka adalah suci (muqoddas). Mawardi berpendirian bahwa kekuasaaan khalifah didasarkan atas "kontrak sosial". Ibnu Khaldun mengakui bahwa banyak menggunakan dasar syari'ah sebagai dasar kebijakan dan peraturan Negara daripada rekayasa otak manusia. Dan Ibnu Taimiyah mendambakan keadilan sebagai prinsip utama pemerintahan. Ia pun mengatakan bahwa Pemimpin (Kepala Negara) yang adil walaupun tidak beragamai Islam lebih baik daripada pemimpin (kepala Negara) yang tidak adil mesikipun beragama Islam.

\section{PRINSIP - PRINSIP PEMERINTAHAN DALAM AL-QURAN}

\section{Isi Kandungan Al-Quran}

Sebagaimana telah dikemukakan pada bagian Pendahuluan tulisan ini, bahwa Al-Quran merupakan suatu norma kehidupan yang sempurna untuk umat manusia dalam seluruh perjalanan hidupnya. Dalam Al-Quran terdapat konsep-konsep etika, politik, ekonomi, dan masyarakat. Di dalam Al-Quran terdapat sejumlah ayat yang mengandung petunjuk dan pedoman bagi manusia dalam hidup bermasyarakat dan bernegara, dalam hal kepemimpinan dan pemerintahan. Ayat-ayat yang berkenaan dengan Pemerintahan, sesuai identifikasi para sarjana Muslim, berjumlah tidak kurang dari 23 ayat tersebar pada 1 surat.

Diantaranya ayat-ayat yang berkenaan dengan "khilafah" (pemerintahan) menjelaskan tentang dua hal, yaitu pertama; tentang kedudukan manusia di muka bumi dan kedaulatan Allah, kedua; tentang prinsip-prinsip yang berkenaan dengan hidup bermasyarakat. Prinsip- 
prinsip tersebut, menurut Munawir Syadzali, meliputi : prinsip Musyawarah, ketaatan dan pimpinan, keadilan persamaan dan kebebasan beragama. ${ }^{11}$ Abu Fariz, ketika membicarakan sistem poliitk Islam, mengemukakan 4 mcam prinsip, yaitu : Keadulatan (milik Allah), Keadilan dan persamaan, taat dan prinsip Syura(musyawarah). ${ }^{12}$ Pada dasarnya kedua sarjana (pemikir Muslim) tersebut memiliki persamaan dalam hal yang diperbincangkan. Uraian berikut ini akan mengkaji prinsip-prinsip pemerintahan sesuai dengan identifikasi yang sudah dilakukan kedua sarjana tersebut.

2. Ayat-ayat Al-Quran tentang Khilafah (Pemerintah)

Bersadarkan referensi yang dijadikan sumber rujukan dapat diidentifikasikan sejumlah ayat sebagai berikut ini; ${ }^{13}$

a. Surat Al-Baqarah (2) ayat 30:

"ingatlah ketika Tuhanmu berfirman kepada para malaikat: Sesungguhnya Aku hendak menjadikan seorang khilafah di muka bumi". Mereka berkata.

b. Surat Al-An'am (6) ayat 165 :

"dan Dialah yang menjadikan kamu penguasa-penguasa di bumi dan Dia meninggikan sebagian kamu atas sebagian (yang lain) beberapa derajat untuk mengujimu tentang apa yang diberikann-Nya kepadamu. Sesungguhnya Tuhanmu amat cepat siksa-Nya dan sesungguhnya Dia Maha Pengampun lagi Maha Penyayang.

c. Surat Al-A'raf (7) ayat 69 :

"dan ingatlah oleh kamu sekalian diwaktu Allah menjadikan kamu sebgai pengganti-pengganti (yang berkuasa) sesudah lenyapnya kaum Nuh,...

d. Surat Shad (38) ayat 26:

"Hai Daud sesungguhnya Kami menjadikan kamu khalifah (penguasa) di muka bumi, maka berilah keputusan (perkara) diantara manusia yang adil dan janganlah kamu mengikuti hawa nafsu karena ia akan meyesatkan kamu dari dari jalan Allah"

e. Az-Zumar (39) ayat 74 :

"Dan mereka mengucapkan: "Segala puji bagi Allah yang telah memenuhi janjinya kepada kami dan telah (memberi) kepada kami tempat ini sedang kami (diperkenankan) menempati tempat dalam surga di mana saja yang

${ }_{11}$ Munawir Syadzali, Islam Dan Tata Negara (Jakarta: UI Press, 1993).h.4

12 Keempat macam prinsip ini dibahas pada BAB pertama dalam bukunya Sistem Politik Islam (diterjemahkan) dari judul aslinya An-Nizam As-siyasi fil -Islam oleh Musthalah Maufur, dengan menggunakan interpretasi dari para pemikir Muslim dan para Mufassirin, dibahas secara luas dan mendalam dan argumentatif dalam 77 halaman.

13 Surat an ayat-ayat dicantukkan pada bagian (2) dan halaman ini dan seterusnya, seluruhnya dikutip dari Al-Qur'an dan Terjemahannya, Penerbit Mujamma' Khadim alHaramain, Madinah, $1141 \mathrm{H}$. 
kami kehendaki". Maka surga itulah sebaik-baik balasan bagi orang-orang yang beramal.

Dari sejumlah surat dan ayat-ayat Al-Quran diatas ada dua kata yang diindikasikan dan pengertian pemerintahan, yaitu kata Khalifah (asal kata: khalafa, Jamak: khalaif) dan kata awrastna (asal kata warasa). Katakata khalifah diberi berbagai arti, seperti : pengganti dan atau penguasa. Kata Awrastna diberi arti (diterjemahkan) : pusakai, menganugrahkan, memberi, mewariskan. Dari dua kata tersebut, dan mmeperhatikan isi dan maksud kandungan ayat, para sarjana (Ulama) lalu memasukkannya ke dalam kelompok ayat-ayat yang berkenaan dengan Pemerintahan (khilafah atau imarah).

3. Prinsip-prinsip Pemerintahan

a. Keharusan adanya Pemerintahan (Negara) Islam

Jika dicermati secara seksama ternyata Al-Qur'an tidak hanya menetapkan prinsip moralitas dan etika, melainkan juga memberi tuntunan dibidang politik, sosial, dan ekonomi. Sanksi-sanksi hukum atas tindakan kriminal, demikian juga tentang kebijakan fiskal dan moneter merupakan bagian yang sangat penting digariskan oleh $\mathrm{Al}-$ Qur'an yang kendatipun secara operasional tidak begitu detail. Ini semua tidak mungkin bisa dipraktekkan kecuali adanya satu pemerintahan (negara) Islam yang menegakkannya. Inilah arti penting dan letak keharusan akan adanya Pemerintahan (negara).

Terdapat sejumlah ayat dalam AL-Qur'an yang dapat dijadikan dasar pijakan, diantaranya seperti Surat Al-Isra (17) ayat 80 :

"Dan katakanlah: "Ya Tuhanku masukkan secara masuk yang benar dan keluarkanlah (pula) aku secara keluar yang benar dan berikanlah kepadaku dari sisi Engkau Kekuasaan yang menolong".

Dalam Al-Qur'an surat An-Nisa ayat 59 berbunyi sebagai berikut: "Hai orang-orang yang beriman, taatilah Allah dan Taatilah Rasul dan ulilAmri diantara kamu.."

Kata Ulil Amri, menurut Muhammad Ali dalam The Holly Qur'an, sebagaimana dikutip Dawam Raharjo ${ }^{14}$ menggariskan tentang urusan pemerintahan, dan orang yang memegang kekuasaan, orang yang mengurusi segala macam urusan umum. Dengan pengertian ini dapat diartikan bahwa urusan umum harus ada yang mengurusnya. Yang memiliki kekuasaan, yaitu pemerintah. Ibnu Taimiyah dalam pemikiran politiknya menyimpulkan bahwa Nabi Muhammad telah diperintah Allah untuk membangun sebuah tata sosial tersebut Nabi juga menyuruh pengikut-pengikutnya untuk menegakkan imarah

\footnotetext{
${ }^{14}$ M.Dawam Rahardjo, Ensikloped Al-Qur'an (Jakarta: Para Madinah, n.d.).h.468
} 
(pemerintahan) apabila beliau sudah wafat, karena tujuan agama tidak bisa direalisir dengan sempurna dan seideal-idealnya tanpa adanya pemerintahan (negara) ${ }^{15}$.

\section{b. Kedaulatan Allah dan Kedudukan Manusia di Muka Bumi}

\section{1) Kedaulatan Milik Allah}

Terdapat sejumlah ayat dalam Al-Qur'an yang menjelaskan realitas bahwa alam ini dan seisinya, dilangit dibumi dan diantara keduanya, yang hidup dan yang mati adalah diciptakan oleh Allah SWT. Dalam surat Al-A'raf (7) : 54, berbunyi : "Sesungguhnya Tuhanmu ialah Allah yang menciptakan langit dan bumi dalam enam hari"

Dalam surat Al-Anbiya (21) : 33, berbunyi : "Dan Dialah yang menciptakan malam diatas siang, matahari dan Bulan"

Allah yang Maha Pencipta dan Dia jualah yang memberi dan menjamin Rizki semua makhluk-Nya. Allah berfirman: "Sesungguhnya Allah yang Maha memberi Rizki, yang Maha mempunyai kekuatan yang amat kokoh". (Adz-Zariyat : 58 )

Atas dasar realita ini maka Allah yang Maha Pencipta dan memberi adalah Pemilik atas semua yang Dia ciptakan dan Dia beri rizki. Allah berfirman: "Dan milik Allah kerajaan langit dan bumi serta antara keduanya. Dia menciptakan apa yang Dia kehendaki". (Al-Maidah : 17).

Sebagai penguasa segala yang Ia ciptakan maka tidak seorangpun menjadi sekutu dalam kerajaan-Nya, sebagimana bunyi firman-Nya : "Segala puji bagi Allah yang tidak mempunyai anak dan tidak mempunyai sekutu dalan kerajaan-Nya, dan Dia bukan pula hina yang memrlukan penolong, dan agungkanlah Dia dengan pengagungan yang sebesar-besarnya." (Al-Isra' : 111 ).

Allah SWT Sebagai pencipta alam semesta, yang memberi rizki yang tidak mempunyai sekutu, Allah Yang Maha mengetahui segala ciptaanNya. Menggariskan pula aturan-aturan bagi manusia secara mendasar, dan Dia mewajibkan manusia agar mengikuti aturan yang telah digariskan itu. (baca : Asy-Syu'ara : 13 ). Abu Farisz. ${ }^{16}$ Menyimpulkan kedaulatan milik Allah dari berbagai keterangan dalam Firman Allah, bahwa sangat jelas kedaulatan hanyalah milik Allah, dan ini merupakan karakteristik uluhiyah yang menjadi milik Allah dan tidak seorangpun berhak mengklaimnya. Pembuat aturan adalah Allah. Yang menghalalkan adalah Allah yang mengharamkan adalah Allah. Realitas ini terkandung dalam kalimat tauhid yang dibawa oleh semua Rasul sejak Adam hinggan Muhammad SAW, sebagaimana firman Allah SWT.

15 Qamaruddin Khan, Pemikiran Politik Ibnu Taimiyah, (Bandung, Penerbit Pustaka, 1983), h.305.

16 Muhammad Abdul Qadir Abu Fariz, Op.Cit., h. 9-12 
"Dan Kami tidak mengirim seorangpun Rasul sebelum kamu melainkan Kami wahyukan kepadanya bahwa tidak ada sesembahan selain Aku. Maka sembahlah Aku". (Al-Anbiya : 25 ).

b. Kedudukan Manusia di Muka Bumi

Sebagai konsekuensi logis dari kedaulatan Allah ( sovereignty of God), maka posisi manusia merupakan khalifahTuhan di bumi. Dan sebagai khalifah tugas manusia adalah melaksanakan dan menegakkan perintah dari pemegang kedaulatan. Allah berfirman dalam surat AlBaqarah : 30 sebagai berikut : ....Tuhanmu berfirman kepada malaikat: "Sesungguhnya Aku akan mengangkat Adam menjadi khalifah dimuka bumi". Pada ayat lain Allah berfirman : "Dan Dialah yang menjadikan kalian penguasa-penguasa dan Dia meninggikan sebagian dari kalian atas sebagian (yang lain) beberpa derajat, untuk menguji kalian tentang apa yang Dia berikan kepada kalian. Sesungguhnya Tuhanmu amat cepat siksaan-Nya, dan sesungguhnya Dia Maha Pengampun lagi Maha Penyayang" (Al-An'am : 165). Dalam surat Yunus : 14 Allah menegaskan : "Kemudian Kami jadikan kalian pengganti-pengganti (mereka) di muka bumi sesudah mereka, agar kami memperhatikan bagaimana kalian berlaku".

Dari ayat Al-Quran tersebut dapat dipahami bahwa posisi dan kedudukan manusia tidak lebih sebagai wakil Tuhan di bumi (khalifah). Khalifah17berarti orang-orang yang menikmati hak-hak atau kekuasaan tertentu yang bukan merupakan haknya sendiri, melainkan hak sebagai wakil atau kuasa Tuhannya. Sifat kewenangannya tidaklah melekat melainkan dilegalisasikan. Sebagai khalifah tidak bebas melakukan sesuai yang dikehendaki, tetapi harus bertindak sesuai dengan pengarahan yang memberi wewenang. Jika demain, tidak mentaati dan merampas kekuasaan yang bukan miliknya sendiri, bahkan bertindak menentang kehendak pemegang kedaulatan (Allah), ini berarti pemberontakan. Manusia akan menjadi setan dan tersesat. 18

3) Prinsip Keadilan

Salah satu kandungan isi Al-Qur'an yang merupakan petunjuk bagi kehidupan manusia dalam bermasyarakat adalah berkenaan dengan keadilan. Ada dua surat yang secara terang menggariskan hal ini, yaitu pada surat An-Nahl : 90 berbunyi: "Sesungguhnya Allah menyuruh (kalian) berlaku adil dan berbuat kebajikan".

Dalam Surat An-Nisa : 58 Allah berfirman : "Sesungguhnya Allah menyuruh kalian menyampaikan amanat keada orang yang berhak

\footnotetext{
${ }^{17}$ Kata Khalifah Dalam Al-Qur'an, selain telah dijelaskan pada bagian awal, dapat dijumpai penjelasan secara lebih luas dan mendetail dalam M. Dawam Rahardjo, Ensiklopedia AlQur'an, dari h. 346-365.

18Muhammad Abdul Qadir Abu Fariz, Loc.Cit.
} 
menerimanya dan apabila menetapkan hukum diantara anusia hendaknya kalian menetapkan dengan adil".

Perhatian Islam sangat besar pada penegakkan keadilan dengan menetapkan kaidah dan prinsip pokok, serta syarat yang harus dipenuhi dalam pemerintahan. Dengan dukungan ejumlah ayat Al-qur'an, dan juga Al-Hadits Islam memberi perhatian yang dipusatkan kepada manusia sebagai anggota masyarakat sebagai objek dan subjek hukum. Para Ulama (fuqaha) bahkan memberi perhatian khusus pada masalah ini dikarenakan menyangkut kemaslahatan dan kebhagiaan hidup manusia Bila mana keadilan dapat diwujudkan maka kehiupan masyarakat menjadi makmur dan sejahtera. Sebaliknya jika kedzaliman yang mewarnai kehidupan maka hidup mereka akan sengsara dan dalam kegelapan. Salah satu tugas khusus Nabi dan Rasul diurunkan kedunia adalah untuk menegakkan keadilan ditengah masyarakat, seperti yang tertera dalam surat Al-Hadid : 25.

Diantara bukti perhatian Islam pada keadilan bahwa Islam menjadikan keadilan sebagai syarat bagi setiap calon pejabat pemerintah, terutama jabatan kepala negara (pemerintah). Ayat 58 Surat An-Nisa berkaitan dengan pemerintahan didasarkan pada ayat selanjutnya yang memang menyangkut soal pemerinthan, yaitu ayat 59, yang agar masyarakat taat kepada mereka yang telahd diberi amanat untuk memegang kekuasaan (ulul-amri). Amanat, dalan ayat 58 itu, dimaksudkan "Pemerintah dan urusan Negara". Oleh karenanya, apabila seseorang telah diserahi amanat pemerintahan, maka ia harus memerintah dengan adil. Jika seseorang telah terpilih menjadi peimpin (pemerintahan) ia harus bisa berdiri datas semua golongan. Untuk itu diperlukan sifat keadilan. Dalam Surat Al-Maidah : 8 Allah berfirman : "Hai orang-orang yang beriman, hendaklah kamu menjadi saksi yang adil. Dan jangan sekali-kali kebencianmu terhadap suatu kaum, mendorong kamu untuk berlaku tidak adil. Berlaku adillah, karena adil itu lebihb dekat kapada taqwa. Dan bertakwalah kepada Allah. Sesngguhnya Allah mengetahu aa yang kamu kerjakan"

Keadilan adalah sesuatu yang benar-benar dituntut pada seorang pemimpin ${ }^{19}$. Oleh karena itulah, maka Ibnu Taimiyah menjadikan syarat utama sifat adil bagi seorang pemimpin, raja atau kepala negara. Statemen dan pendirian Ibnu Taimiyah ini dapat dilihat dalam ungkapan sebagai berikut : Kepala Negara meskipun kafir adalah lebih baik dari pada kepala negara yang tidak adil (zalim) meskipun Islam.

\footnotetext{
${ }^{19}$ Baca surat Shad ayat 22 Tentang Nabi Daud a.s yang diminta untuk memberi suatu keputusan yang adil dalam menghadapi masalah yang muncul.
} 
4) Prinsip Persamaan dan Kasih Sayang

Prinsip persamaan yang digariskan dalam Al-Qur'an terdapat dalam surat Al-Hujurat : 13 dimana Allah berfirman : Hai sekalian manusia, sesungguhnya kami menciptakan kamu berbangsa-bangsa dan bersuku-suku agar saling mengenal. Sesungguhnya orang yang paling mulia disisi Allah adalah orang yan paling bertaqwa diantara kalian", Dalam surat An-Nisa ayat 1 Allah berfirman : "Hai sekalian manusia, bertaqwalah kepada Allah Tuhanmu yang menciptakan kamu dari jiwa yang satu dan dari keduanya berkembang laki-laki dan perempuan".

Dari dua ayat tersebut diatas manusia dipandang sama kedudukannya disis Tuhan. Kriteria yang membuat seseorang mempunyai keunggulan atas orang lain tidak terletak pada keturunan, etnis, warna kulit, bahasa, dan status sosial, melainkan pada sejauh mana keteguhannya berpegang pada perintah-perintah Allah dan ketaqwaan kepada-Nya. Prinsip persamaan dalam Islam bukan hanya sekedar prinsip pada dataran retorika, melainkan prinsip pada dataran normatif dan dalam realitas kehidupan. Umat Islam telah mempraktekan prinsip tersebut terutama Rasulullah SAW. Beliau tidak membedakan anatara kaum lemah dengan hamba sahaya dengan para ningrat Quraisy, antara kaya dan miskin, antara muslim dengan non muslim. Realitas ini ditunjukan baik ia sebagai seorang Nabi maupun sebagai kepala pemerintahan Negara Madinah, sebagaimana tercermin didalam piagam Madinah, sebagaimana tercerin didalam piagam Madinah. Realitas kehidupan seperti ini dilanjutkan oleh para Khalifah sesudah Nabi, terutama Abu Bakar, Umar bin Khattab, serta Ali bin Abi Thalib. ${ }^{20}$

Prinsip persamaan dan kasih sayang dalam suatu pemerintahan (Islam) tampak pada Al-Qur'an surat An-Nur : 55 yang berbunyi : "Allah telah menjanjikan kepada orang-orang yang beriman dan mengerjakan kebajikan kepada orang-orang yang beriman dan mengerjakan kebajikan bahwa Dia akan memberikan kekhalifahan kepadamereka dibelahan bumi ini". Ayat ini cukup jelas bahwa kekhalifahan tersebutdijanjikan pada segenap masyarakat muslim. Oleh karena itu, sifat-sifat kekhalifahan yang dijanjikan adalah kekhalifahan universal tidak terbatasnya pada individu atau sekelompok orang. Konsekuensinya adalah semua masyarakat bertanggung jawab atas urusan Negara yang telah dibangun berdasarkan kehendak rakyat dan bekerja sejalan dengan kekuasaan yang telah didelegasikan oleh masyarakat. Bagaimana cara pemerintah mendekati masyarakat ? Petunjuk AL-Qur'an sudah jelas, sebagaimana firman Allah dalam surat Al-Imron : 159 sebagai berikut : "Karena rahhmat Allah-lah engkau bersikap lemah lembut terhadap mereka. Sekiranya engkau bersikap keras dan berhati bengis, tentulah mereka akan

20Muhammad Abdul Qodir Abu Fariz, Op. Cit., h. 27-29 
menjauh darimu. Karena itu maafkanlah mereka, Mohonkan ampun bagi mereka dan muyawarahkan dengan mereka dalam berbagai urusan".

Dari ayat-ayat diatas dapat diambil kesimpulan pendekatan pemerintah terhadap rakyatnya harus didasarkan atas kasih sayang, rasa simpati dan kebesaran hati. Pemerintah harus coba untuk meringankan beban mereka, sekaligus memberikan rasa aman dan nyaman. Pemerintah harus mengusahakan kesejahteraan, kehidupan yang lebih layak dan kemakmuran bagi masyarakat seluruhnya. Tujuan Negara (Pemerintahan) menurut Al-Qur'an sesungguhnya adalah penegakan kebajikan dan membasmi kemungkaran. Dan ini merupakan tugas bagi siapa yang Allah beri kekuatan pada merka, sebagaimana firman-Nya dalam surat Al-Hajj : 41 sebagai berikut: "(Orang-orang Muslim itu) ialah yang jika kami beri mereka kedudukan kuasa dimuka bumi, mereka mengerjakan, menunaikan zakat, menyuruh berbuat kebajikan, dan melarang berbuat kemungkaran". Ayat ini mengarahkan tujuan negara (pemerintahan) dalam Islam dan memberikan landasan bagi karakteristik dasar para pemegang dan pengatur kekuasaan pemerintahan. ${ }^{21}$ 5) Prinsip Ta'at

Jika ditelaah secara seksama terdapat ayat Al-Qur'an yang mewajibkan umat Islam mentaati da patuh kepada Umara dan melarang menentang mereka. Prinsip ini dapat ditemukan pada ayat 59 surat An-Nisa, sebagai berikut : "Wahai orang-orang yang beriman, taatilah Allah dan taatilah Rasul, dan pemimpin diantara kalian dan jika kalian berlainan pendapat tentang sesuatu maka kembalikanlah kepada Allah dan Rasul kalau kalian benar-benar beriman kepada Allah dan hari kemudian. Yang demikian itu lebih utama (bagi kalian) yang lebih baik kesudahannya". Ayat ini, dilihat dari struktur bahasanya, berbentuk imperatif (amr), yang konsekuensinya adalah wajib selama tidak ada indikasi yang didukung keterangan yang mengubah statusnya menjadi sunnah. Dan ternyata dalam ayat ini tidak terdapat korinah (konteks) yang mengalihkan pengertian pemerintah menjadi sunnah. Jadi ayat ini menegaskan kewajiban taat pada ulil-amri. Sedangkan mentaati Allah adalah melaksanakan perintah-perintah-Nya, dan mentaati Rasul adalah mentaati sunnah-nya serta mengikuti perintah-perintahnya. Taat kepada ulil-amri yaitu seperti pada khalifah, para amir, komandan pasukan, gubernur, dan menteri serta orang-orang yang mengemban tugas dan tanggung jawab urusan umat (Islam). Kewajiban taat kepada Amir dipertegas oleh Nabi dalam sabdanya, sebagai barikut: "Barang siapa mentaati aku maka ia telah mentaati Allah, dan barang siapa menentang engkau maka ia telah menentang Allah. Barang siapa mentaati amir, maka telah mentaati aku, dan barang siapa menentang Amir maka ia telah menentang aku"22

${ }^{21}$ Abul 'Ala Al-Maududi, Op.Cit., h.207.

22Abu Fariz, Op.Cit., h.46 
Meskipun Islam telah mewajibkan rakyat taat pada pimpinan. Akan tetapi ketaatan itu tidak bersifat mutlak dan bebas dari ikatan. Persyaratanpersyaratan tertentu dan wilayah tertentu harus terpenuhi, yaitu Pertama; Pemimpin yang dimaksud ialah pemimpin yang memiliki komitmen yang kuat pada syari'at Islam dan menerapkn dalam kehidupan. Hal ini sesuai dengan apa yang tertera dalam An-Nisa : 54 tersebut, yaitu mengembalikan kepada Alla (Al-Qur'an) dan Rasul (Sunnahnya) jika terjadi selisih paham atau suatu masalah yang tidak bisa dipecahkan. Kedua; Memerintah yang Adil. Apabila pimimpin menegakkan keadilan maka rakyat wajib mentaatinya. Sebaliknya, apabila pemimpin bertindak zalim, maka bukan saja tidak wajib mengikutinya melainkan justru menentangnya. Ketiga ;tidak menyuruh menusia berbuat maksiat. Pada prinsipya para pemimpin berkewajiban melaksanakan amar ma'ruf nahyi mungkar, menyebarluaskan perbuatan terpuji serta memerangi perbuatan tercela. ${ }^{23}$

Tegasnya, memang Islam telah menetapkan bahwa taat adalah suatu kewajiban seorang muslim, dalam hal yang disukai maupun yang tidak disukai selama tidak dipertahankan untuk melakuka maksiat. Apabila terjadi demikian, menyuruh maksiat, maka tidak ada kewajiban taat.

6) Prinsip Syura (Musyawarah)

Salah satu kandungan ayat Al-Qur'an yang sangat menonjol berkaitan dengan pemerintahan adalah prinsip syura (musyawarah) dalam berbagai literatur tentang ketatanegaraan, sistem politik Islam, maupun pemikiran-pemikiran politik, para sarjana muslim menaruh perhatian yang sangat besar dan menjadikan tema ini bagian dari tulisan mereka. Para pemikir modern semisal, Fazlur Rahman, Bernard Lewis,Al-Maududi dan Abu Fariz adalah diantaranya yang telah menulis dan berdiskusi tetang Syura sebagai prinsip dalam konstitusi Islam.

Konsep Syura yang terdapat dalam Al-Qur'an merupakan sebuah prinsip penting berkaitan dengan hal sosial keberagaman Islam. Kata Syura atau Musyawaraholeh pemikir modern dianggap sebagai doktrin kemasyarakatan dan kenegaraan yang fundamental. Nash Al-Qur'an demikian jelas. Dalam surat Al-Imron : 159 Allah berfirman : "Dan bermusyawarahlah dengan mereka tentang urusan ( yang penting)itu". Ayat ini turun di Madinah tatkala masyarakat Islam telah mulai terbentuk. Walaupun bunyinya merupakan perintah kepada Nabi Muhammad SAW dan turun dalam konteks peran Uhud, Nama para ahli tafsir menjadikan ayat ini sebagai prinsip kemasyarakatan dan kenegaraan. Dalam ayat AlSyura' ayat 38 berbunyi : "Dan (bagi) orang-orang yang mematuhi seruan Tuhannya dan mendirikan Shalat, sedangkan urusan mereka (diputuskan) dengan bermusyawarah diantara mereka. Dan mereka meafkahkan sebagian rizki yang kami berikan kepada mereka."

23Ibid.,h. 48-49 
Kedua ayat dari dua surat yang berbeda tersebut mengandung prinsip ang sama yaitu berkenaan dengan doktrin kemasyarakatan dan kenegaraan yang pokok. Prinsip musyawarah, sebagaimana diperintahkandalam Al-Qur'an, telah didukung oleh tradisi Nabi Muhammad SAW sepanjang hidupnya. Nabi Muhammad SAW sepanjang hidupnya. Nabi Muhammad SAW adalah orang yang paling banyak meminta pertimbangan keoada para sahabatnya. Umpamanya pada waktu perang Badar, beliau berabda: "Berilah aku pendapat wahai sekalian manusia". Beliau mengulangi kata ini lebih dari satu kali. Demikian juga pada peperangan lain yang dipimpinnyaa, seperti peran Khandak dan eraang Hudaibiah. Dan masih banyak hal dalam fenomena kehidupan para sahabat beliau yang dapat diselesaikan lewat pintu musyawarah.

Tradisi Syura24 (musyawarah) ini dilanjutkan oleh para sahabat sepeninggal Nabi Muhammad SAW. Abu Bakar meminta pendapat Umar bin Khattab dalam masalah-masalah yang tidak ditemukan nashnya dalam Al-Qur'an maupun dalam sunnah Rasulullah SAW. Mengenai musyawarah ini Umar bin Khattab berkata : "Tidak ada kebaikan dalam suatu urusan yang diputuskan tanpa dengan musyawarah", sedang Hasan Basri mengatakan : "Suatu kaum selagi bermusyawarah tidak akan sesat dan urusan mereka menjadi terarah". Hakekat Syurara, menurut Abu Fariz, adalah pembagian tanggung jawab yang mana akibatnya meskipun berada dipundak seorang tapi saling tuding kesalahan. Diantara manfaat yang paling penting dari bermusyawarah adlah menjadikannya sarana untuk mengungkap kemampuan dan kesiapan sehingga dapat mengambil manfaat dari kemampuan mereka. Manfaat lainnya ialah bahwa syura atau musyawarah melatih ikut andil dalam pemerintahan, memperkaya pengalaman, mengasah penalaran akal selama bermusyawarah. ${ }^{25}$

Mengomentari ayat 38 As-Syura (42), Al-Maududi menyatakan bahwa ayat tersebut memberitahukan kepada kita megenai gambaran istimewa dari jalan kehidupan Islami, yaitu semua urusan kelompok masyarakat dilaksanakan secara musyawarah. Ayat ini bukan sekedar pernyataan mengenai suatu realitas saja, melainkan sebagai perintah dan peraturan. Menganai cara-cara musyawarah Al-Maudadi menyerahkannya kepada kaum muslimin. Islam tidak mengharuskan model pasti dalam pembentukan majelis permusyawaratan dengan alsan bahwa Islam merupakan agama universal yang diperuntukan bagi semua zaman dan situasi. Oleh karena itu, Islam tidak menetapkan apakah rakyat harus bermusyawarah secara langsung ataukan melalui wakil-waki yang mereka

\footnotetext{
${ }^{24}$ Terminologi Syura, dapat ditemui dalam berbagai Ensiklopedi, seperti Ensiklopedi Al-Qur'an susunan M.Dawam Rahardjo (1996). Istilah Syura diuraikan dalam 20 halaman ( 440-460).

Baca juga : Abu Fariz, Sistem Politik Islam (2000), h.53.

${ }^{25}$ Abu Fariz,Op.,Cit., h. 56
} 
percayai, apakah pemilihan harus dilakukan melalui pemilihan umum atau melalui lembaga -lembaga pemilihan. Hal-hal tersebut sangat kondisional dan situasional. Namun, dalam konteks ayat tersebut diatas dan dari tradisi Nabi Muhammad SAW. Ada tiga hal sangat penting yang merupakan prinsip syari'ah, yaitu :

a. Musyawarah dilakukan untuk memilih kepala Negara yang akan mendepak monarki, depotisme dan kediktatoran.

b. Musyawarah harus bebas dan murni, tidak memihak, tidak ada tekanan.

c. Semua rakyat yang berkepentingan harus diajak bermusyawarah secara langsung atau melalui wakil-wakil yang mereka percaya. ${ }^{26}$

\section{KESIMPULAN}

Al-Qur'an merupakan suatu norma kehidupan yang sempurna bagi umat manusia. Didalam terdapat konsep-konsep mengenai etika, politik, ekonomi, dan masyarakat. Terdapat sejumlah ayat yang mengandung petunjuk dan pedoman dalam hidup bermasyarakat dan bernegara, dalam hal kepemimpinan dan pemerintahan. Diantara ayat-ayat yang berkenaan dengan khalifah (pemerintahan) mengandung penjelasan yang berkenaan dengan : kedaulatan Allah dan posisi manusia dimuka bumi, serta beberapa prinsip yang berkenaan dengan hidup bermasyarakat.

Allah Maha pencipta segala sesuatu. Allah lah pemilik kerajaan langit dan bumi, dengan dibekali instrument pengatur rambu-rambu kehidupan. Mulalui utusan-Nya Rasulullah SAW, Allah memberi perintah untuk membangun tatanan sosial sesuai dengan syari'ah. Dan Rasulullah SAW menyuruh oengikut-pengikutnya untuk menegakkan imarah (pemerintahan) guna merealisasi tujuan agama. Tatanan etika dan tatanan politik tidak mungkin bisa dipraktekkan kecuali dengan adanya pemerintahan.

Para pemikir Muslim telah mengidentifikasikan prinsip-prinsip pemerintahan dalam Al-Qur'an, meliputi keadilan, taat dan prinsip musyawarah. Prinsip-prinsip pemerintahan tersebut merupakan landasan yang paling ideal bagi suatu sistem politik Islam (pemerintahan) yang dapat membawa kesejahteraan dan kemakmuran masyarakat, apabila yang memerintah (pimpinan) maupun yang dipimpin dapat menegakkan keadilan, mentaati dan melaksanakan tugas dan tanggung jawab, serta semua persoalan dipecahkan secara musyawarah.

\section{DAFTAR PUSTAKA}


Al-Qur'an dan terjemahannya, (Madinah Munawarah, Mujamma' Khadim AlHaramain Asy-Syarifain, $1411 \mathrm{H}$ )

Afzalazurrahman, Indeks Al-Qur'an, (Jakarta, Bumi Aksara, 1997).

Abu Fariz, Muhammad Abdul Qadir., Sistem Politik Islam, (Jakarta, rabbani Press, 2000, Penterjemah Musthalah Mauruf MA.

Al-Maududin., Abul 'Ala., Hukum dan Konstitusi Sistem Politik Islam, Bandung, Penerbit Mizan, 1993 ), cetakan kedua.

Dewan Redaksi, Ensiklopedi Islam, (Jakarta, Ikhtiar baru van Hope, 1993)

Hamid, Tijani Abd.Qodir, Pemikiran Politik Dalam Al-Qur'an, (Jakarta, Gema Insani Press, 2001), penerjemah Abdul Hayyie Al-Kattani.

Khan, Qomaruddin., Pemikiran Politik Ibnu Taimiyah, (Bandung Penerbit Pustaka, 1983), terjemahan Anas Mahyuddin.

Mumtaz Ahmad., ed., Teori Politik Islam, (Jakarta, Paramadinan, 1996), cetakan ketiga.

Raharjo M. Dewan., Ensiklopedi Al-Qur'an, (Jakart, Paramadina, 1996), cetakan kesatu.

Syadzali, H.Munawir., Islam dan Tata Negara, (Jakarta, UI Press, 1993). 